\title{
Commentary: Wildlife Conservation and Canada's North
}

\author{
A. H. MACPHERSON
}

RÉSUMÉ. "Wildlife Conservation and Canada's North" par A. H. Macpherson (préparé par Yves Labrèche, Laboratoire d'Archéologie, UQAM).

Selon Martin (1967), les chasseurs venus d'Asie qui ont peuplé l'Amérique, ont contribué a l'extinction de plusieurs espèces de grands mammifères du Pléistocène; puis ils s'adaptèrent en s'attaquant aux espèces moins vulnérables; ainsi s'établit une relation plus stable jusqu'à l'époque de l'arrivée des Européens. Alors commence l'expoitation intensive des animaux à fourure, tel le castor. Au XIXe siècle, les bisons furent décimés lors du processus de colonisation des terres agricoles; de même l'orignal et le caribou furent exploités pour approvisionner l'équipage des baleiniers, les explorateurs et pionniers. Des lois et règlements durent être institués.

Malgré la croyance améridienne voulant qu'il existat autrefois une entente spirituelle entre l'homme et les espèces sauvages, l'auteur prétend que lors de la période de contact ni les autochtones ni les allochtones pratiquant une économie d'autosubsistance n'exerçaient un contrôle raisonné sur les ressources fauniques. Quelques modèles sont présentés pour définir les modes d'adaptation des populations de chasseurs, compte tenu des comportements du gibier dans l'espace, de son abondance relative, de l'interaction des espèces et des fluctuations climatiques.

Autrefois, la petite taille des groupes de même qu'une technologie simple auraient empêché de dépasser le niveau critique de prises. Aujourd'hui, la plus grande efficacité des techniques de chasse commande l'instauration d'une reglémentation efficace.

Dans une perspective historique, la conservation consiste en une politique visant à perpétuer les stocks constitués tout en ne consommant que les surplus. La transformation de propriété collective des ressources en propriété privée serait nécessairement engendrée par la surexploitation. L'example de la Convention de la Baie James et d'une entente semblable conclue au Manitoba illustrent duex formes de droits d'utilisation des ressources obtenus par les Amérindiens.

Aujourd'hui le défi est double: il faut découvrir des solutions nouvelles et autochtones aux problèmes de conservation des ressources fauniques particulières au Canada, et structurer l'utilisation des ressources, y compris les ressources industrielles.

In comparison to most parts of the world, Canada has a short history of human pressure on natural resources. North America has been extensively occupied by Man for possibly as little as thirteen thousand years. The immigrants from Asia, via Beringia, were hunters, and it has been shown (Martin, 1967) that their advent extended a process which had long been current in the Old World the depletion of the varied large mammal faunas of the Pleistocene era. Canada's present game animals are the survivors of the process. "We must beg the question of just how and why prehistoric man obliterated his prey. We may speculate but we cannot determine how moose, elk and caribou managed to survive while horse, ground sloth, and mastodon did not"' (Martin, 1967).

By the time that the present, dwindling, tide of immigration and colonization began in the early 1500 s, the great wave of mammal extinctions had long subsided, and a more stable relationship had become established between Man and wildlife. Amerindians, however, remained hunters (although some tribes practiced agriculture) and most, particularly in the North, lived in scattered, small, impermanent camps. Some of the earliest descriptions of Canada's North vividly describe these conditions of life (e.g. Hearne, 1795).

With the immigrants came new pressures on wildlife, perhaps first on the fur-bearers, upon which the natives quickly became dependent for the means to barter goods from the traders. Thus, the formerly ubiquitous beaver had become scarce in many localities as early as 1850 , and had almost vanished from large parts of the country by 1930. The North American bison was also brought to the verge of extinction in the latter half of the 19th century. Certain species, such as moose and Barren Ground caribou, were made to bear additional harvests to feed whaling crews, explorers, miners and pioneers. As these depletions caused outcry, so laws and regulations were instituted to control harvests, and such measures as ranching and restocking were instituted as required to perpetuate the game.

Amerindians may look back on the time before the tide of immigration as one in which Man lived in harmony with Nature, and infer that a special relationship must have existed between Man and wildlife. It was widely believed, among native North Americans, that they had been created by a Great Spirit to live integrally with the natural world in a network of interdependencies. Their prophecies spoke of invasion by outsiders, despoliation of the environment, and repetition of the creative act in a sequence of cycles.

We cannot be sure, however, that Amerindian societies differed in their attitudes toward conservation from the European societies which also lived at the edge of subsistence. What evidence we have may lead to the conclusion that none of these societies "managed" its wildlife resources in any sense of the word.

The pattern of distribution of the Great Auk, a species now extinct, is a case in point. Well-attested breeding localities were on islands and islets off the Scottish, Ice- 
landic and Canadian shores, Funk Island off Fogo Island (Newfoundland) and St. Kilda off the Outer Hebrides (Scotland) being examples. The historian of the "Great Auk, or Garefowl", Symington Grieve (1885), wrote of the birds' distribution in the eastern North Atlantic: "If it ever existed very numerously . . . it would fall an easy prey . . . until the few colonies that remained were confined to outlying islets . . ."; and of the western parts of its range in similar terms: "Here also the Garefowl . . . had become confined to islets to which it could not be followed by the Red Indian in his frail canoe . .."

Another example of the absence of a wild species from those parts of its potential range inhabited by humankind is provided by the Canadian explorer Vilhjalmur Stefansson (1913), who observed that muskoxen and Inuit nowhere co-existed. Muskoxen were vulnerable to people because their defensive behaviour was developed to protect them against the attacks of wolves. They habitually form circles, with the powerfully horned adults usually in the outer ring, a strategy that is useless against men armed with weapons as simple as spears. Helped by dogs, the hunters would keep the herd together; approaching, they would jab a spear at the animal's forehead, and when the head was tossed up, thrust it deep into the base of the neck. Explorers encountered (and of course, slaughtered) considerable numbers of muskoxen, but never near Inuit villages.

From a wildlife management perspective, what opportunities for resource stewardship seem to have been foregone! We must remind ourselves that this perspective is not an endowment of mankind, but a fruit of time and circumstance.

Wildlife management for sustained yield is today a sophisticated, scientific activity which seeks to accommodate social desires in wildlife without damage to the resource. Historically, however, it is a product of the feudal society, and began as an imposition on the wanting by the wealthy. It is a craft rooted in privilege and not in poverty.

If indeed Amerindians of the contact period did not practice some form of wildlife husbandry, why is it so difficult to find examples, such as Great Auk and muskox, of species clearly over-exploited before European immigration?

One factor contributing to the fate of these two examples could be their sedentary natures: more mobile migratory species would seem less likely to be destroyed by humans lacking the capacity to follow lengthy migratory routes.

A more basic factor is the relationship between population characteristics of the prey on the one hand and the predator on the other. A decrease in the numbers of prey, for example, will lead to a decrease in the numbers of predators, which in turn should give the prey species an opportunity to increase. A simple predator-prey model might fit the relationship between Inuit numbers and population size of the ringed seal in a particular locality, the ringed seal being a resource (food and fuel) for which substitutes did not exist. In such a model, the Inuit would not be effective enough as hunters to exterminate the seal, and the numbers of seals then would determine the size of the human population. But Inuit depending on seals could perhaps exterminate nearby populations of more vulnerable species (such as muskoxen) which, being nonstaples, had no feed-back control on the Inuit.

More elaborate models are required to explain predatorprey systems which comprise more than one species on each side. Thus, ringed seals are taken also by polar bears and sometimes by walrus and killer whales; their pups are taken also by arctic foxes. Inuit also took other species of seal, and whales, as well as certain birds, fish and land mammals. But for each season there was some staple game for which there were no substitutes. This staple species, by influencing human survival, ensured its own.

We can thus imagine a model of a human population, its prey populations, and associated interactors oscillating about some sustainable balance between populations of predators and yields of prey. Another model might be visualized depending for its specific dynamic on the low biotic productivity and diversity of arctic ecosystems and the effect of unreliability, or instability, of climatic conditions on marginal production seasons. For example, the length of the growing season, or the snow-free season, varies between wide limits from year to year. Some springs, consequently, no young geese are raised because snowfall persists too long. Some years the vegetation attains little or no new growth; some years ice in lakes never melts, and never clears in bays. Freezing rain or thawing and freezing snow at a critical time of year will make foraging impossible for birds, and particularly for mammals such as muskox and caribou. Such gross environmental variations - persistence of fast ice, late snows, and summer droughts, for example, may interfere with an already limited annual production, at the plant or animal level, and drastically affect the availability of an important food. Arctic ecosystems are not nearly as diverse as tropical or even temperate ecosystems: the number of species declines rapidly as latitude increases. To a subsistence people in the North this may mean that when a resource becomes scarce there are few, or no, opportunities for substitution.

These features of the North - unreliability and low biotic production and diversity - may together act to control human populations depending on local resources. Thus, by their very instability, arctic prey populations could perhaps have kept predator populations - including human ones - within stringent bounds.

There seems no evidence, then, that wildlife was purposefully managed by Amerindian populations in northern Canada at the time of contact. Instead, we may conjecture that the impact of hunting on wildlife stocks was limited only by the low technological level of the hunters and the fact that their populations were small and insecure. 
Great Auk and muskox were admittedly unusually vulnerable. Other species, and I will mention specifically arctic ones, were less so. The Barren Ground caribou, geese, and fish such as arctic char, were (and are) vulnerable in the sense that they are easily taken in large numbers at particular times and places, but (given the earlier native technologies) not so vulnerable that even mass slaughter at these points of access in their annual cycles could much affect their abundance.

The Barren Ground caribou, whose Eurasian counterparts are reindeer, comprise several populations, each of which migrates regularly in spring into high, windswept parts of the Barren Grounds to calve and pass the short summer season, and returns to the forests for the winter, where the snow falls lightly in the still air and can easily be pawed away to expose the lichens upon which the animals depend. The spring migrations of the caribou take them across frozen rivers and lakes but on their return in the autumn, they must swim the now ice-free waters. This they do at crossings used year after year, and there they have traditionally been ambushed by native hunters. The hunter would set off in a small vessel, a kayak or a canoe to intercept the swimming herd. He would then jab as many as he could in the kidney area, inflicting fatal wounds that, however, permitted his victims to gain the shore before conveniently collapsing on the bank. A winter's meat supply could be quickly obtained in this manner.

Several kinds of geese migrate north to breed in the Canadian Arctic, of which the snow and blue geese are the most gregarious. The birds arrive already paired, and once settled, often in continuous colonies, the goose begins to incubate while the gander attends nearby. When the goslings are hatching, their parents are starting to shed their flight feathers, and parents and young are then, for a few weeks, confined to land.

During the egg-laying, people living within range of the colonies stocked up on this excellent food source. Later, when the geese were still flightless but well grown, Inuit rounded them up into stone enclosures where they could be caught and killed. The major harvesting of geese by arctic people occurred at these vulnerable periods. Today, egging and selective hunting (adults are preferred) of the flightless birds is practised to a limited extent: many more geese are killed as migrants, with shotguns.

The arctic char is the most important food fish to Inuit of the arctic coast. It also has vulnerable periods because it is an anadromous fish, living during summer in the productive seas and through the winter in oligotrophic freshwater lakes. Twice a year arctic char thus pass in schools through small, shallow rivers which connect the lakes to the sea.

In former days, Inuit built weirs and pounds, composed of boulders between which water could flow, across the lower rapids of these rivers. The upstream run was the one most fished because the ascending fish by then had gained weight in the sea, and also because low water made for the best conditions. One person would steal out along the weirs to close gaps, left to facilitate the entry of the fish. Then, everyone who felt able to spear or grab a char would jump into the cold water and begin the work. Several tons of fish could be caught in this manner, at a communal weir, in a few days.

Many such traditional ways of the Inuit have been abandoned, including hunting customs. Spearing caribou at water crossings and char at stone weirs, and driving flightless geese into enclosures, are pursuits followed by very few contemporary Inuit. The rifle, motorboat and snow vehicle have replaced the kayak and caribou spear, and the net and spinning rod the fish spear: the new technologies have extended the vulnerability of wildlife populations in both time and space. The much greater effectiveness of their new technologies, in conjunction with the de-coupling of the former controls on the populations of harvesters, now make effective regulatory controls essential.

The animal resources of the Canadian Arctic that are currently of greatest concern are:

1) Narwhal and walrus: Relatively easily killed with modern boats and rifles, these large sea mammals have impressive and distinctive ivory tusks for which lucrative markets exist. Harvests are closely controlled under quota by Canadian authorities, though too many are killed but lost and never retrieved.

2) Bowhead: Greatly reduced by American and Scottish whalers a century ago, neither eastern nor western populations have recovered their former abundance. Their depleted numbers still sustain a harvest in Alaska, regulated under the International Whaling Convention (but again this fishery has a most unfortunately high rate of accidental loss). There is no legal harvest of bowhead in Canadian waters.

3) Caribou: Some of the herds of Barren Ground caribou, particularly the Kaminuriak herd, have been over-exploited for several decades and are considerably diminished. The individually smaller Peary caribou has greatly declined in numbers in recent years due to climatic conditions on its range in the High Arctic. The native harvest is a matter for concern in both cases (the rising demand for cervid antlers, which figure in Asiatic pharmacopoeia, could well affect future conservation).

4) Polar bear: Because of the high price of skins on international markets, the polar bear harvest is closely regulated in Canada; thus, legal harvesting should pose no threat. A recent experiment has shown that oil pollution could be a danger to polar bears if oil on the pelt is ingested, and the federal government is taking this problem into account in the licensing of ventures which pose threats of oil pollution. Canada is a party to an international convention on polar bears designed 
mainly to curtail hunting on the high seas, specifically around Svalbard and Bering Strait. Our concern for domestic stocks is to ensure perpetuation of an important resource to the native people.

5) Migratory birds: The significant Inuit uses of migratory birds are localized and are directed toward very common species. Proposed amendments to Canada's Migratory Birds Convention with the United States should permit improvements to the present regulatory system. Though the losses of sea-birds to salmon drift-nets off West Greenland is a serious continuing problem, our worst worries over migratory birds in the Canadian Arctic concern possible future oil spills.

Conservation is historically based on a prudent, futureoriented outlook that has parallels in agriculture (preserving the breeding stock) and capitalism (living off the interest). As the economics of production and, perhaps more dramatically, inflation, have devalued resource futures, so the economic rationale for conservation has lost much of its validity. Conservationists therefore rationalize with arguments that are emotional, often ethical, noneconomic and sometimes frankly counter-economic. We base our appeals on the welfare of coming generations and on uncertainties (unknown consequences, resource needs and impacts on human health).

Though inflation probably was not a factor in Amerindian economic policy, similar concerns may have inhibited the development of a conservation outlook. First, the future was too uncertain to count as a motivating factor: foregoing opportunities to take wildlife was too dangerous in relation to greatly discountable future benefits. Second, it was possible to reduce to the point of extinction any marginal or non-vital resource, if sufficiently vulnerable, but it was never possible to so reduce a staple resource.

Perhaps the question posed by Martin quoted in the first paragraph of the article can be answered: mammal extinctions were within the capabilities of Pleistocene hunters only because there were other species to provide a continuing resource base as the more vulnerable were in the process of being annihilated. In the wary surviving game species, the Pleistocene hunters eventually found the responsiveness to exploitation rates that made a reasonably stable predator-prey relationship possible (see also Edwards, 1967).

Changes in social outlooks may lag behind social needs. In this regard, it is interesting to contrast the reindeer societies of Eurasia with the caribou societies of Canada and Alaska. The Lapps and other peoples of Northern Europe and Asia own almost all of the reindeer herds, whether privately or collectively. The conservation of these herds is thus in the hands of those who have the exclusive right or opportunity to harvest them. Our caribou hunters, however, regard the caribou as a common property resource. They have not been responsive to government regulation of the kill because, as native people, they have unlimited, traditional rights to hunt for food on public land.

The question of conservation of common versus private property has been illuminated by Garrett Hardin (1968), who suggests that the division of common property resources among private owners is a step forced on societies by their over-exploitation. His illustration is the medieval grazing commons:

"The tragedy of the commons develops in this way. Picture a pasture open to all . . . each herdsman will try to keep as many cattle as possible on the commons. Such an arrangement may work reasonably satisfactorily for centuries . . . Finally, however, comes the day of reckoning ... As a rational being, each herdsman ... asks, "What is the utility to me of adding one more animal to my herd?" . . . the herdsman concludes that the only sensible course for him to pursue is to add another animal to his herd. And another, and another . . . Ruin is the destination to which all men rush, each pursuing his own herd interest ... Freedom in a commons brings ruin to all."

Canadian native peoples as a whole enjoy no proprietary rights in wildlife. Treaties struck between the Crown and various tribes through their leaders of the time do, however, guarantee broad hunting rights. Interpretation by the courts of subsequent legislation (i.e., the Natural Resource Transfer Acts, the Migratory Birds Convention Act) has tended to restrict the wildlife hunting privileges of native Canadians (Cardinal, 1977).

The treaties, then, have not established a basis for an understanding between the Canadian native and larger societies. Numerous provisions were left for later settlement, including selection of reserve lands: subsequently, great differences of opinion have developed concerning such matters. Although from a legal perspective the treaty provisions may be reasonably clear, doubts have been raised as to the weight that can now be attached to them, given the current awareness of the cultural gulf between and pressures on the parties thereto at the time of negotiation (Price, 1979).

From the larger society perspective, however, these and later negotiations have concerned the extinguishment of native rights by compensation in cash and kind. Wildlife resources have figured in such negotiations, particularly in the James Bay Agreement, which may be referred to as an example.

Hydro-Québec, the provincial electric utility, is constructing a series of dams and generating stations on rivers in the James Bay area of Northern Québec. The impact on the existing native peoples and their ways of life was expected to be so devastating that extensive discussions were required, culminating in the James Bay and Northern Québec Agreement of 1975. The object was to negotiate compensation in land, cash and wildlife.

In effect the Agreement (Québec, 1976) gives the native Cree and Inuit of northern Québec exclusive hunting, fishing and trapping rights over an area of $150000 \mathrm{~km}^{2}$, and exclusive rights to certain species - moose and caribou in particular - over the entire northern half of the Province. However, granting exclusive hunting rights 
stopped short of vesting the people with the responsibilities of ownership, because the governments concerned reserved the right to prevent the harvesting of any species if its continued existence becomes endangered.

A somewhat similar Agreement was entered into in 1977 by the Province of Manitoba, the Federal Government, the Manitoba Hydro-Electric Board, and native communities affected by major generating projects, represented by the Northern Flood Committee, Inc. The terms of the "Four-Party Agreement" (Manitoba, 1977), however, suggest that the residents of the Indian reserves have negotiated something very close to proprietorial rights to the wildlife lying in their traditional resource harvesting area. They possess first priority to these resources and others will be in fact prohibited from using them, except when "it is in the interests of the perpetuation of ... overabundant species to permit ... a controlled season ....". Manitoba agreed to establish a Wildlife Advisory and Planning Board, but its responsibilities are only ". . . to consider and recommend on all matters affecting wildlife within the Resource Area ...".

It is too early to evaluate the success of these recent developments, which in effect couple stewardship with utilization in the management of wildlife resources in Northern Canada. However, some problems have been predicted in the particular case of the geese of James Bay, migratory birds which are shared as a quarry by hunters in the U.S. and southern Canada, as well as the northern Cree (Boyd, 1977).

I have described certain problems of conservation in northern Canada, and speculated on solutions, without giving more than passing mention to what may become our most serious and unmanageable short-term problem, that of oil pollution on our arctic seas and shores. The Government of Canada repeatedly faces decisions with respect to oil exploration, production and transport in the Arctic. These are being made against a background of conflicting public opinion: certain native groups want aboriginal land claims settled before sanctioning resource development; certain other citizens' groups want the effort devoted instead to reducing consumption and advancing the conserver society; and others, of course, press the need for secure domestic oil supplies.

The Canadian government's current northern development policy statement (Canada, 1972), outlined the criteria by which industrial development proposals for the Yukon and Northwest Territories were to be judged. These criteria emphasized the social objectives and the environmental concerns of the Department of Indian and Northern Affairs. Social development has since been slow, owing to the low level of economic activity at the community level and the enormous, rising expense of infrastructure; localized environmental degradation has attracted considerable national attention, and, although the economic incentives for oil and gas exploration have shown themselves susceptible to policy change, industrial activity has continued, in reaction to current supply short- falls. In other words, the social problems, the environmental concerns and the industrial thrusts have all shown more momentum than reconciliation. Accommodations can no doubt be achieved: the world oil price will evidently provide a margin over exploration and production expenditure that could cover with less cost to the general economy the high costs of infrastructure in the North. Land use conflicts can no doubt be resolved: the Arctic is, after all, extremely sparsely populated. What seems required is a more elaborate policy for the ' 80 s that will incorporate a regional planning approach to resource development, and a stake in resource revenues for northern communities.

Canada's twin northern conservation challenges are, from the foregoing perspective, to find indigenous and innovative solutions to unique Canadian resource conservation problems, and to place northern resource uses, including industrial uses, on a planning foundation.

\section{ACKNOWLEDGEMENTS}

I am grateful to several colleagues for comments, specifically F. L. Miller, T. H. Wood, A. E. Collin and J. Gérin of Environment Canada, A. Gunn of the N.W.T. Government, and particularly I. A. McLaren of Dalhousie University. Thanks are due also to Claudette Reed-Upton for help with the text.

\section{REFERENCES}

BOYD, HUGH. 1977. Waterfowl hunting by native peoples in Canada: the case of James Bay and northern Quebec. In: Proceedings of the XIIth Congress of Game Biologists. 463-473.

Canada. 1972. Canada's North 1970-1980. IAND Publication No. OS3015-000-HB-A-1, Ottawa. 40 p.

CARDINAL, HAROLD. 1977. The Rebirth of Canada's Indians. Edmonton: Hurtig. 222 p.

EDWARDS, W.E. 1967. The late-Pleistocene extinction and diminution in size of many mammalian species. In: Martin, P.S. and Wright, H.E. Jr. (eds.). Pleistocene Extinctions/The Search for a Cause. Vol. 67. Proceedings VIIth Congress, International Association for Quaternary Research. New Haven and London: Yale University Press. $453 \mathrm{p}$.

GRIEVE, SYMINGTON. 1885. The Great Auk, or Garefowl (Alca impennis, Linn.). Its History, Archaeology, and Remains. London: Thomas C. Jack. 141 p. + 58 p. Appendix.

HARDIN, GARRETT. 1968. The tragedy of the commons. Science 162: 1243-1248.

HEARNE, SAMUEL. 1795. A journey from Prince of Wales's Fort in Hudson's Bay to the Northern Ocean. 1769. 1770. 1771. 1772. Glover, R. (ed.). Pioneer Books edition. 1958. Toronto: Macmillan. 301 p.

Manitoba (Province of). 1977. Agreement Dated the 16th Day of December 1977 Between Her Majesty the Queen in Right of the Province of Manitoba of the First Part and the Manitoba Hydro-Electric Board of the Second Part and the Northern Flood Committee, Inc. of the Third Part and Her Majesty the Queen in Right of Canada as represented by the Minister of Indian Affairs and Northern Development of the Fourth Part. 74 p. + 44 p. Schedules A-G.

MARTIN, PAUL S. 1967. Prehistoric overkill. In: Martin, P.S. and Wright, H.E. Jr. (eds.). Pleistocene Extinctions/The Search for a Cause. Vol. 67. Proceedings VIIth Congress, International Association for Quaternary Research. New Haven and London: Yale University Press. 75-129.

PRICE, RICHARD (ed.). 1979. The Spirit of the Alberta Indian Treaties. Institute for Research on Public Policy, Toronto. 202 p.

Québec (Editeur officiel de). 1976. James Bay and Northern Québec Agreement. 455 p.

STEFANSSON, V. 1913. The distribution of human and animal life in Western Arctic America. Geographical Journal 41: 449-460. 